Acta technologica agriculturae 1

Nitra, Slovaca Universitas Agriculturae Nitriae, 2013, p. 26-30

\title{
SOIL RESISTANCE AND ITS IMPACT ON TILLAGE DEPTH
}

\author{
František VARGA, Miroslav MOJŽIŠ, Rudolf ABRAHÁM \\ Slovak University of Agriculture in Nitra, Slovakia
}

\begin{abstract}
Currently manufactured tractors are equipped with a three-point hitch, which is used to connect semi-mounted implements to the tractor. The tractor three-point hitch is operated hydraulically, using various types of control. The most commonly used control is a force, positional and a mixed one. Each of these types of control has its specific characteristics and some advantages and disadvantages. Finally, each type of control is suitable for certain soil and terrain conditions. Particular attention was paid to a force control, which is improving the use of the tractor with a mounted implement, but on the other hand, adversely affects the uniformity of working depth of implements on soils with variable resistance. Based on theoretical analysis and experimental measurements, there has been determined the effect of soil resistance on the tillage depth, depending on initial conditions for implement deepening. Initial conditions for implement deepening are given by the tillage depth, soil resistance, and the cutting width of a plough. It was found that soil resistance strongly affects the tillage depth, and with increasing soil resistance the tillage depth decreases non-linearly. A gradual increasing of soil resistance is associated with a less-marked decreasing of the tillage depth. These facts will be further used in research, development and experimental verification of new control systems of the three-point hitch of tractors.
\end{abstract}

Keywords: soil resistance, soil compaction, three-point hitch control, uniformity of tillage depth

Currently, tractors are equipped with a three-point hitch (TPH) that is hydraulically actuated by different types of control. The most common is a positional, force and mixed control. The purpose of all of these controls is to ensure a balanced distribution of mounted tools with respect to the tillage depth. Experimental measurements have confirmed that each type of control is suitable for specific soil and terrain conditions. The control mechanism performs its function by maintaining the controlled value. In this article, attention is being paid to the force control. In this case, the control mechanism controls the resistance value of implements by changing their working depth. The purpose of this article is therefore to study the effect of soil resistance on tillage depth uniformity.

It is known that the soil is not homogeneous, and its resistance changes by tillage. The tillage depth will change by using the force control, which is not satisfactory from an agronomic point of view. Therefore, attention is being paid to this issue to see the effect of soil resistance on the tillage depth with the force control of the tractor TPH.

\section{Material and methods}

The force control regulates the working depth of implements on the basis of changes in implement resistance, and

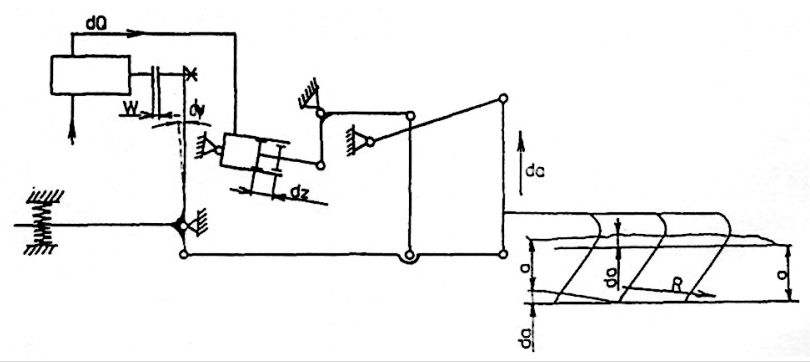

Figure 1 The principle of a traditional force control of tractors that affects changes in force ratios in the tractor TPH. For the purpose of control, it is possible to change the force in the upper rod or lower rods of the TPH. In general, the force control from the lower rods of the TPH is used almost exclusively.

The principle of a traditional force control of tractors is shown schematically in Fig. 1.

Working resistance $R$ affects the working bodies of mounted implements. Increasing the working resistance by the value $d R$ due to increased working depth by the value $d a$ causes that the force in the TPH lower rods increases by the value $d F$. An increased force in the lower rods causes that the pulse meter lever is rotated by an angle $d \psi$. When the upper end of the pulse meter lever makes a distance $W$, the force control is actuated. The spool of the internal circuit of the hydraulic directional control valve is moved into the position 'lifting'. Then, a certain amount of pressure oil $d Q$ is supplied to the hydraulic cylinder of the TPH lifting device, the piston of which is moved by the value $d z$. This ultimately means that the implement is lifted up, and the working depth is lower, thus ensuring the original force ratios in the TPH.

The implement working resistance can be expressed as follows:

$$
R=a \cdot b \cdot n \cdot k, \quad \mathrm{~N}
$$

The total cutting width of the implement:

$$
B=b \cdot n, \quad \mathrm{~m}
$$

Equation (1) will then be as follows:

$$
R=a \cdot B \cdot k, \quad \mathrm{~N}
$$

The implement working resistance $R$ is a function of two variables, i.e. the working depth $a$ and soil resistance $t$ :

$$
R=f(a \cdot k), \quad \mathrm{N}
$$


Partial derivatives of Equation (3) can be expressed as follows:

$$
\begin{aligned}
& \frac{\partial R}{\partial a}=B \cdot k \\
& \frac{\partial R}{\partial k}=a \cdot B
\end{aligned}
$$

The total derivative of working resistance is then:

$$
d R=\frac{\partial R}{\partial a} \cdot d a+\frac{\partial R}{\partial k} \cdot d k
$$

By substituting in Equations (5) and (6) we get:

$$
d R=B \cdot k \cdot d a+a \cdot B \cdot d k
$$

The TPH force control is based on the following relationship:

$$
a=z \cdot i, \quad \mathrm{~m}
$$

The equation expresses a relationship between the piston position $z$ of the lifting device and the implement working depth $a$. The value $i$ expresses the transmission ratio of the lifting device.

By differentiation of Equation (9) we obtain:

$$
d a=d z \cdot i
$$

Transmission ratio $i$ is considered constant within the control range.

The control process takes a certain period of time; therefore, we divide Equation (10) by the differential of time and obtain:

$$
\frac{d a}{d t}=\frac{d z}{d t} \cdot i
$$
follows:

The speed of piston motion can then be expressed as

$$
\frac{d z}{d t}=v_{p}
$$

Assuming that the hydraulic pump is delivering a constant amount of fluid $q$ during the control process, the speed of piston motion can be expressed as follows:

$$
v_{p}=\frac{q}{S_{p}}, \quad \mathrm{~m} \cdot \mathrm{s}^{-1}
$$

By substituting in Equation (11) we get:

$$
\frac{d a}{d t}=\frac{q}{S_{p}} \cdot i
$$

After modification, we obtain the following:

$$
d a=\frac{q}{S_{p}} \cdot i \cdot d t
$$

At the same time:

$$
d a=\frac{d R}{k \cdot B}
$$

By substituting in Equation (15) we get:

$$
\frac{d R}{k \cdot B}=\frac{q}{S_{p}} \cdot i \cdot d t
$$

If the value $d R$ is expressed by Equation (8), Equation (17) will be as follows:

$$
\frac{B \cdot k \cdot d a \cdot a \cdot B \cdot d k}{k \cdot B}=\frac{q}{S_{p}} \cdot i \cdot d t
$$

After designating $q \cdot d t=d Q$, which is the amount of fluid supplied to the hydraulic cylinder during the control process, and adjusting Equation (18), we get:

$$
d a+a \cdot \frac{d k}{k}=\frac{d Q}{S_{p}} \cdot i
$$

The last relation indicates that the control mechanism is at rest if the following condition is satisfied:

$$
d a+a \cdot \frac{d k}{k}=0
$$

This condition is fulfilled if the following applies concurrently:

$$
\begin{gathered}
d a=0 \\
a \cdot \frac{d k}{k}=0
\end{gathered}
$$

or when:

$$
d a=-a \cdot \frac{d k}{k}
$$

Then, the control mechanism will be put into operation whenever the tool resistance changes. In case of the force control, two failure variables are the implement working depth and soil resistance.

Equations (21) and (22) represent a steady state if the working depth corresponds to the required value and soil resistance is constant. Equation (23) is also a steady state if a change in the working depth $a$ is corrected by variations in soil resistance $k$. Generally, however, both members of Equation (20) take a variable value. The smaller the proportion of the second member in the control process, the better the force control is. In terms of agronomical practices, the worst case occurs when the working depth is constant for flat terrain and soil resistance changes. This means that the control system will cause an undesirable change in the working depth of a mounted implement.

Accordingly, it is necessary to do an impact analysis of soil resistance on a change in the mounted implement working depth for the force control.

Equation (23) indicates that a change in soil resistance $d k$ causes a change in the working depth $d a$ :

$$
d k=-\frac{k}{a} \cdot d a
$$

After modification, we obtain:

$$
\frac{d a}{a}=-\frac{d k}{k}
$$

After integration:

$$
\begin{aligned}
& \int \frac{d a}{a}=\int-\frac{d k}{k} \\
& \ln a=-\ln k+c
\end{aligned}
$$


Furthermore, we express the integration constant $c$ as follows:

$$
C=\ln C
$$

By substituting in Equation (27) we get:

$$
\ln a=-\ln k+\ln C
$$

By modifications we further get:

$$
\ln a=\ln \frac{C}{k}
$$

The working depth $a$ results therefrom as follows:

$$
a=\frac{c}{k}
$$

The last relation indicates that with the force control the working depth $a$ is inversely proportional to soil resistance $k$ for initial conditions of the constant $C$.

For initial conditions for implement deepening $a_{0^{\prime}} k_{0^{\prime}}$ initial implement resistance $R_{0}$ is given by the following equation:

$$
R_{0}=a_{0} \cdot B \cdot k_{0}, \quad \mathrm{~N}
$$

The force control maintains a constant implement resistance:

$$
R_{0}=R=\text { constant }, \quad \mathrm{N}
$$

By substituting for $R=a \cdot B \cdot k$ we get:

$$
a_{0} \cdot B \cdot k_{0}=a \cdot B \cdot k, \quad \mathrm{~N}
$$

\begin{tabular}{|c|c|c|c|c|c|c|}
\hline \multicolumn{7}{|c|}{ Standard hydraulics - force control } \\
\hline \multirow{2}{*}{$\begin{array}{l}\text { Position of } \\
\text { control lever }\end{array}$} & \multirow{2}{*}{$\begin{array}{l}\text { Position of } \\
\text { lifting arms }\end{array}$} & \multirow{2}{*}{$\frac{\text { Nominal force } \mathbf{F}}{\mathrm{N}}$} & \multicolumn{2}{|c|}{ Maximum force $F$} & \multicolumn{2}{|c|}{ Minimum force $F$} \\
\hline & & & $\mathrm{N}$ & $\%$ & $\mathrm{~N}$ & $\%$ \\
\hline 6 & $-16^{\circ}$ & 44,500 & 49,500 & 111.2 & 39,000 & 87.6 \\
\hline 7 & $-7^{\circ}$ & 37,500 & 41,000 & 109.3 & 31,000 & 82.7 \\
\hline 8 & $2^{\circ}$ & 27,500 & 32,000 & 116.4 & 22,500 & 81.8 \\
\hline 9 & $11^{\circ}$ & 16,000 & 19,500 & 121.9 & 10,500 & 65.6 \\
\hline
\end{tabular}

Then, the working depth $a$ will be:

$$
a=a_{0} \cdot \frac{k_{0}}{k}, \quad \mathrm{~N}
$$

Table 1 Characteristics of a standard mechanical force control

Table 2 Values $F, a_{\text {min.' }} a_{\text {max. }}$ and $k_{\text {min. }}, k_{\text {max. }}$ for the initial conditions: $a, b, n, k$-force control

\begin{tabular}{|l||c|c|c|c|c|}
\hline Initial conditions: $a=20, b=30, n=5$ & 60 & 70 & 80 & 90 & 100 \\
\hline Soil resistance $k$ in $\mathrm{kPa}$ & 18,000 & 21,000 & 24,000 & 27,000 & 30,000 \\
\hline Nominal force $F$ in $\mathrm{N}$ & 12,500 & 15,790 & 19,000 & 22,000 & 24,750 \\
\hline Minimum force $F_{\text {min. }}$ in $\mathrm{N}$ & 21,580 & 25,000 & 28,470 & 31,580 & 34,360 \\
\hline Maximum force $F_{\text {max. }}$ in $\mathrm{N}$ & 13.89 & 15.04 & 15.83 & 16.30 & 16.50 \\
\hline Minimum tillage depth $a_{\text {min. }}$ in $\mathrm{cm}$ & 23.97 & 23.81 & 23.72 & 23.39 & 22.91 \\
\hline Maximum tillage depth $a_{\text {max. }}$ in cm & 41.6 & 52.6 & 63.3 & 73.3 & 82.5 \\
\hline Minimum soil resistance $k_{\text {min. }}$ in $\mathrm{kPa}$ & 71.9 & 83.3 & 94.9 & 105.3 & 114.5 \\
\hline Maximum soil resistance $k_{\text {max. }}$ in $\mathrm{kPa}$ & & & & & max. \\
\hline
\end{tabular}


Table 3 The effect of soil resistance on the tillage depth for the initial conditions: $a, b, n, k$

\begin{tabular}{|c|c|c|c|c|c|c|c|}
\hline \multicolumn{8}{|c|}{ Initial conditions: $a=20, b=30, n=5, k=60 \mathrm{kPa}$} \\
\hline Soil resistance $\mathrm{k}$ in $\mathrm{kPa}$ & 30 & 40 & 50 & 60 & 70 & 80 & 90 \\
\hline Tillage depth $a$ in $\mathrm{cm}$ & 40.00 & 30.00 & 24.00 & 20.00 & 17.14 & 15.00 & 13.33 \\
\hline \multicolumn{8}{|c|}{ Initial conditions: $a=20, b=30, n=5, k=70 \mathrm{kPa}$} \\
\hline Soil resistance $\mathrm{k}$ in $\mathrm{kPa}$ & 40 & 50 & 60 & 70 & 80 & 90 & 100 \\
\hline Tillage depth $a$ in $\mathrm{cm}$ & 35.00 & 28.00 & 23.33 & 20.00 & 17.50 & 15.55 & 14.00 \\
\hline \multicolumn{8}{|c|}{ Initial conditions: $a=20, b=30, n=5, k=80 \mathrm{kPa}$} \\
\hline Soil resistance $k$ in $\mathrm{kPa}$ & 50 & 60 & 70 & 80 & 90 & 100 & 110 \\
\hline Tillage depth $a$ in $\mathrm{cm}$ & 32.00 & 26.66 & 22.86 & 20.00 & 17.17 & 16.00 & 14.54 \\
\hline \multicolumn{8}{|c|}{ Initial conditions: $a=20, b=30, n=5, k=90 \mathrm{kPa}$} \\
\hline Soil resistance $k$ in $\mathrm{kPa}$ & 60 & 70 & 80 & 90 & 100 & 110 & 120 \\
\hline Tillage depth $a$ in $\mathrm{cm}$ & 30.00 & 25.71 & 22.50 & 20.00 & 18.00 & 16.36 & 15.00 \\
\hline \multicolumn{8}{|c|}{ Initial conditions: $a=20, b=30, n=5, k=100 \mathrm{kPa}$} \\
\hline Soil resistance $\mathrm{k}$ in $\mathrm{kPa}$ & 60 & 70 & 80 & 90 & 100 & 110 & 120 \\
\hline Tillage depth $a$ in $\mathrm{cm}$ & 33.30 & 28.57 & 25.00 & 22.22 & 20.00 & 18.18 & 16.66 \\
\hline
\end{tabular}

on the loading force in the TPH lower rods, with specifying the values of upper and lower control deviation. In this case, control deviation expresses the sensitivity of control.

The characteristics of the control system for the Zetor 16145 tractor is given in Table 1 and graphically illustrated in Figure 2.

Further, it is necessary to determine the value of plough working resistance according to a simplified Gorjačkin's equation as follows:

$$
R=a \cdot b \cdot n \cdot k, \quad \mathrm{~N}
$$

The calculated values of plough resistance depending on soil resistance for initial conditions are given in Table 2 .

Initial conditions for implement deepening are explicitly given by:

- tillage depth $a$,

- ploughshare cutting width $b$,

- number of ploughshares $n$.

Thus, the calculated plough working resistance corresponds to the nominal force in the TPH lower rods. Based on the experimentally determined characteristics of the control system shown in Figure 2, the minimum and

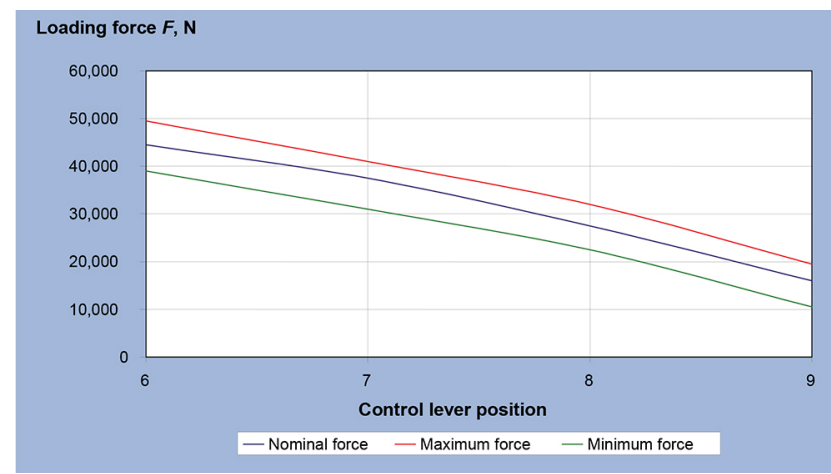

Figure 2 Characteristics of a standard mechanical force control maximum values of force are specified for each value of nominal force.

Then, the minimum and maximum value of soil resistance is determined using the following equation:

$$
\begin{array}{ll}
k_{\text {min }}=\frac{F_{\text {min }}}{a \cdot b \cdot n}, \quad \mathrm{kPa} \\
k_{\text {max }}=\frac{F_{\max }}{a \cdot b \cdot n}, \quad \mathrm{kPa}
\end{array}
$$

Similarly, the minimum and maximum tillage depth will be determined on the basis of nominal force $F$, i.e. by using the following relations:

$$
\begin{aligned}
& a_{\min }=\frac{F_{\min }}{b \cdot k \cdot n}, \quad \mathrm{~cm} \\
& a_{\max }=\frac{F_{\max }}{b \cdot k \cdot n}, \quad \mathrm{~cm}
\end{aligned}
$$

Finally, the effect of soil resistance on the tillage depth will be determined for initial conditions of implement deepening:

$$
a=\frac{F}{b \cdot n \cdot k}, \quad \mathrm{~cm}
$$

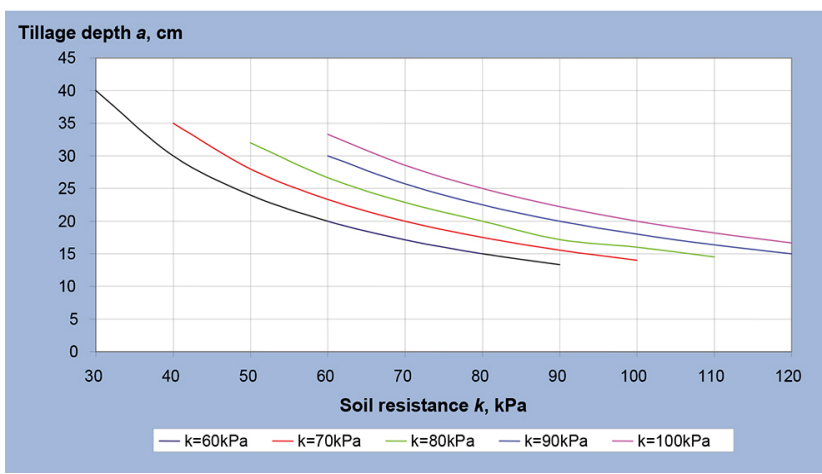

Figure 3 The effect of soil resistance on the tillage depth for the initial conditions $a=20, b=30, n=5$ 
In that respect, it should be noted that in practical calculations we substitute in Equation (44) the values of nominal force listed in Table 2 for initial conditions. In this way, we calculate the values of tillage depth depending on soil resistance, which values are listed in Table 3 and graphically illustrated in Figure 3.

\section{Results and discussion}

The results obtained confirm that with the TPH force control the soil resistance significantly influences the uniformity of mounted implement working depth. As seen from the figures shown in Table 2 and from the graph in Figure 3, soil resistance has a significant effect on loading force in the TPH lower rods for the given initial conditions.

The above-mentioned numerical and graphical data clearly show that with the TPH force control the relationship between the tillage depth and soil resistance is non-linear in all cases, irrespective of initial conditions during implement deepening. The presented graphical illustrations further show that non-linearity gradually decreases with increasing soil resistance, and the individual courses take a linear character to some extent. A non-linear relationship between the tillage depth and soil resistance follows moreover from Equation (44).

Because any real control system works with certain control deviations, as follows from the entries in Table 1 and the graphs shown in Figure 2, it will be further necessary to theoretically and experimentally analyse the impact of control sensitivity on the uniformity of mounted implement working depth. This requirement is particularly up-to-date because all modern tractors are equipped with an electrohydraulic control of the TPH that allows a smooth adjustment of control sensitivity. After setting the maximum control sensitivity, the value of control deviation is reduced to a minimum, so the control mechanism practically maintains a constant working resistance of the mounted implement. The above-mentioned facts will be ultimately reflected in a different effect of soil resistance on the tillage depth. However, in any case, it is necessary to fully take into account the cutting width of the mounted implement and the required working depth.

\section{Conclusion}

In the present article, there is determined, based on the theoretical analysis, the effect of soil resistance on the uniformity of mounted implement working depth with the force control of the TPH. Based on the theoretical analysis and experimental measurements, there was determined the effect of soil resistance on the tillage depth, depending on initial conditions during implement deepening. Initial conditions for implement deepening are given by the tillage depth, soil resistance, and the cutting width of the plough.

The above-mentioned facts have not yet been analysed based on current knowledge. Therefore, a certain part of the results presented herein is original. In that respect, it is necessary to assess the overall results presented in this paper. It should be noted that there has been a plethora of experimental measurements of soil resistance performed at home and abroad. However, the impact of soil resistance on the uniformity of mounted implement working depth was not analysed and presented in this form.

It is expected that the practical application of the results obtained enables the agro-technical requirements to be widely met as regards the uniformity of working depth, especially for primary soil processing. Finally, the results obtained provide appropriate conditions for a further development of science and technology in the given scientific area.

Acknowledgement

Supported by the Ministry of Education of the Slovak

\section{References}

Republic, project VEGA 1/0857/12 'Reduction of unfavourable impacts of agricultural and transport machinery on the environment'.

ABRAHÁM, R. - JABLONICKÝ, J. - ŠVEC, O. - VARGA, F. 2008. Influence of surface deformation of soil to change of the bulk density in soil profile. In Traktori i pogonske mašine (Novi Sad, Srbija), pp. 8593. ISSN 0354-9496.

ABRAHÁM, R. - JABLONICKÝ, J. - VARGA, F. - DRLIČKA, R. 2009. Design of increase interaction properties of tyres in worsenees climatic conditions. In Traktori i pogonske mašine (Novi Sad, Srbija), pp. 64-69. ISSN 0354-9496.

DRABANT, Š. - TKÁČ, Z. - ABRAHÁM, R. - CVÍČELA, P. - MAJDAN, R. 2007. Ťahové vlastnosti traktora FENDT 926 VARIO. In Vozidlá 2007. Nitra : SPU, s. 31-36.

KUČERA, M. 2006. Analýza trecích dvojíc a skúšky opotrebenia materiálov. In Zborník vedeckých prác Nové trendy v konštruovaní a v tvorbe technickej dokumentácie 2006. Nitra : SPU, s. 59-64. ISBN 80-8069-701-9.

MOJŽIŠ, M. - FINDURA, P. 2008. Analiza efekasnosti uništavanja korova termičkom plevilicom. In Revija agronomska saznanja, godište 18, godina 2008, broj. 5, p. 80. ISSN 0354-2092.

VARGA, F. - JABLONICKÝ, J. - MÜLLEROVÁ, D. - ŽIKLA, A. 2009. Influence of soil resistance on ploughing depth. In Traktori i pogonske mašine (Novi Sad, Srbija), pp. 49-58. ISSN 0354-9496.

VARGA, F. 2009. Analýza silových a kinematických závislostí pri prenose energie pojazdovým ústrojenstvom : písomná práca na dizertačnú skúšku. Nitra : SPU.

\section{Contact address:}

Ing. František Varga, PhD., Ing. Miroslav Mojžiš, PhD.; Ing. Rudolf Abrahám, PhD.; Department of Transport and Handling, Faculty of Engineering, SUA in Nitra, Tr. Andreja Hlinku 2, 94976 Nitra, Slovakia, ㅍㅛㅛ +421 37641 4531, e-mail: frantisek.varga@uniag.sk 